\title{
Study on Tourism Management Professional Experience Type Design Model
}

\author{
Bing Mi \\ Jilin Business and Technology College, 130062, Changchun, China \\ E-mail: 57409609@qq.com
}

\begin{abstract}
China's tourism education follows the traditional "classroom teaching as the center, take the teacher as the center, take the knowledge infusion as the center" the teaching model, this pattern of trained personnel finally just in creative and pioneering consciousness of defective adoptive talents. In order to improve the tourism professional talent training quality, therefore, must be to tourism management professional teaching model for the new positioning and thinking, On the reform of teaching mode is imminent. This paper mainly discusses the tourism management professional experience type teaching mode, Experience type teaching mode as a kind of new teaching concept, to improve the teaching quality, to foster talents of high quality has a positive role.
\end{abstract}

Keywords- tourism management, professional, experience type, model, design

\section{INTRODUCTION}

Tourism talent is vital conditions for tourism development, and the development level of tourism education and determines the tourism talent training and development. The dependency on look, tourism education standpoint is tourism, focus on in education. By introducing the experience type teaching mode not only make the whole tourism teaching system is being perfected, also made the higher education reform research field more widely. At the same time also enriched the content of tourism research, to seek tourism teaching mode theoretical basis, sets up a high quality, innovative talents in tourism industry, the education system has important contribution. Through the tourism management professional experience type teaching mode, construct efficient tourism management professional teaching mode, This is not only beneficial to promote the development of tourism education, so as to cultivate more talents, innovative tourism professional talents, improve the tourism reception level, At the same time also for tourism sustained, rapid and healthy development lay a good foundation.

\section{EXPERIENCE TYPE TEACHING}

Experience type teaching, refers to the process of teaching, according to the students' cognitive characteristics and rules, through the creation of the actual or repeated experience situation and opportunity, present or representation, reducing the teaching content, so that students in the process of close to understand and construct knowledge, development ability, produce emotion, and formation the meaning of the teaching and the teaching form [1].

\section{A. The Characteristics of Experiencing Type Teaching Mode \\ Experience type teaching mode characteristics is as follows.}

1) Experience. This is the essential characteristics of experience type teaching, experience is different from personal experience, and It includes: (1) the level of practice experience, namely subject through the practical action to experience something. (2) Psychological experience, namely subject in psychological, virtual "experience" something. Experience type teaching advocated in the teaching activities, students will no longer be passive recipients of knowledge, but they claim in the teaching activity, from the behavior and emotional directly involved in the teaching activities, through their own experience marriage construct knowledge.

2) Individuality. There are kinds of differences between each subject, the subjectivity level is differ, the interest hobby different, the understanding of the things different, so the experience is not the same.

3) Silent. Experience is the main body experience, means that the subject from the experience gained rich inner feeling, To present another subject is concerned, some components can be language, others only can sense, not words, which can be called "silent knowledge".

4) Entertainment. Experiential learning for entertaining the study opens a new train of thought. "fun" is not the teachers themselves making fun, but students to experience the fun. The fun should include two layers of meaning: One is the teacher teach knowledge into can stimulate the students' interest in teaching methods, try to make teaching as attractive as entertainment. The second is the teacher through arouse the enthusiasm of students' study, the passive learning into active control process, make the student to make clear the purpose of study, and to experience the happiness of study [2].

\section{B. The Basic Process of Experience Type Teaching Mode}

Experience type teaching is through the "situational Settings - subject experience - evaluation experience migration experience" process, the study of theme with students' life combining actual. The teachers and students use cooperation way in emotional communication, thinking collision of experience, feeling, and gradually influence, and promote the student to obtain and master professional knowledge a kind of teaching method. 
The first stage: the situation Settings. The teacher's behavior in the experience type teaching process is stimulating activity. At this stage, teachers focus on the guide students together to build situation, give full play to the thinking and operation skills to take part in the situation of creating.

The second stage: Subject experience. The key lies in the student's main body status in the experience of reveal. Students in the independent construction activities experience, such as through the operation of the skills, speech atmosphere, role playing and the means to participate in the intellectual, emotional, accept the whole process of the present.

The third stage: the evaluate experience. By the teacher went to the seat, to guide and of the tester's identity to join the students experience activities, through guide the student to the knowledge, emotion for introspection, to help student's present self experience, and companion to experience the purpose of communication.

The fourth stage: migration experience stage. This is a beyond the classroom meaning stage, the teacher guides the student to develop the field of vision to activities outside the classroom. Use the student to the knowledge of the consensus, the emotions to stimulate students' thirst for knowledge and experience other situation yearning.

Experience type teaching mode character

Use the "Header 2" style, shown above,

\section{PROBlEM OF TOURISM MANAGEMENT PROFESSIONAL TEACHING MODE}

At present, in the tourism management professional teaching, organization form in collective teaching is given priority to, Teaching methods to teach is given priority to, discussion method, experimental method with less, teaching program basic are set in stone "five stages" teaching. Teachers' freedom degree is bigger, students' freedom degrees is small, with the teacher as the center, teaching lack of students' participation, the teaching activity is a single way, the classroom atmosphere is not active. The teaching characteristics description of the current tourism management professional teaching mode basically belongs to the traditional teaching mode. This kind of teaching mode for the system knowledge has its successful place, but for modern students' information ability, cooperation ability, innovation ability training has ragged. At present professional tourism management teaching mode there are the following problems and defects [3], main performance is:

(1) Tourism professional teaching thought stale, teaching target single

(2) Tourism professional curriculum chaos, teaching content relative lag

(3) The teaching process rigid, teaching methods outdated

(4) In the tourism professional teaching arrangements exist on the practice teaching of the narrow and hysteresis

(5) Tourism professional teachers' strength is weak, lack of teachers' professional knowledge

\section{The EXPERIEnCE Type TEACHING Mode AND the CURRENT TEACHING MODE COMPARISON}

Research shows that: "reading information, we can remember ten percent; hear information, we can remember twenty percent; but have experienced things, but we can remember eighty percent." Experience type teaching mode with the similar mechanism, as Washington museum written on the wall: I hear, I forgot. I see, I remember. I do, I understand. Experience type teaching mode has broken the traditional teaching mode of teaching organization form; arouse the enthusiasm of the students to participate in the study, to the traditional "take the classroom as the center and the teacher is given priority to, knowledge infusion is given priority to" in terms of teaching mode is a new breakthrough and development, It with the traditional teaching mode difference [4], can be seen in table 1

TABLE I. THE EXPERIENCING TYPE TEACHING MODE AND TRADITIONAL TEACHING MODE DIFFERENCE

\begin{tabular}{|c|c|c|}
\hline $\begin{array}{c}\text { Basic } \\
\text { element }\end{array}$ & $\begin{array}{c}\text { Traditional } \\
\text { teaching mode }\end{array}$ & $\begin{array}{l}\text { Experience type } \\
\text { teaching mode }\end{array}$ \\
\hline $\begin{array}{l}\text { Learning } \\
\text { unit }\end{array}$ & personal & $\begin{array}{ll}\text { Team } & \text { and } \\
\text { personal }\end{array}$ \\
\hline $\begin{array}{l}\text { Learning } \\
\text { model }\end{array}$ & Individual learning & $\begin{array}{l}\text { Students learn } \\
\text { from each other }\end{array}$ \\
\hline $\begin{array}{l}\text { Learning } \\
\text { points }\end{array}$ & $\begin{array}{ll}\text { Single study and } \\
\text { through } \\
\text { professional } \\
\text { knowledge }\end{array}$ & $\begin{array}{l}\text { Multi-level study, } \\
\text { to explore } \\
\text { professional } \\
\text { knowledge other } \\
\text { than related } \\
\text { concepts }\end{array}$ \\
\hline $\begin{array}{l}\text { Study } \\
\text { nature }\end{array}$ & cognitive & $\begin{array}{l}\text { Cognitive, } \\
\text { understand and } \\
\text { grasp }\end{array}$ \\
\hline $\begin{array}{l}\text { The role of } \\
\text { students }\end{array}$ & $\begin{array}{l}\text { Passive acceptance } \\
\text { - listen, write, test } \\
\text { Unidirectional } \\
\text { receiving }\end{array}$ & $\begin{array}{l}\text { Participate in the } \\
\text { entire process of } \\
\text { plan, implement, } \\
\text { control and } \\
\text { summary } \\
\text { feedback }\end{array}$ \\
\hline $\begin{array}{l}\text { Role of } \\
\text { Teachers }\end{array}$ & $\begin{array}{l}\text { Speaker } \\
\text { assessment }\end{array}$ & $\begin{array}{l}\text { The classroom } \\
\text { scene } \\
\text { construction / } \\
\text { Assistant }\end{array}$ \\
\hline
\end{tabular}

\section{Mode Design of TOURISM MANAgEMENT} PROFESSIONAL EXPERIENCE TYPE TEACHING

Experience type teaching mode is to the traditional teaching mode a bold attempt and innovation, Experience type teaching mode is to the traditional teaching mode a bold attempt and innovation, in the design of tourist professional experience type teaching mode, we can from the following aspects:

\section{A. Change the Teaching Idea, the Experience Type Teaching as the Value Orientation of Tourism Management Teaching}

Teaching mode reform lies in the reform of teaching concept, to construct the teaching mode in accordance with the requirements of times, must abandon does not conform to the requirement of teaching idea, establish the scientific , and meet the requirements of the times concept of teaching. To 
develop the tourism industry and that match the development of high quality tourism professionals, we must deepen the reform of tourism education. "Take the student as the main body, the teacher as the leading" as the basic goal, from "cramming" examination education into "experiential" quality education, "pay more attention to students' experience" experience type teaching as a professional tourism management teaching value orientation, Fundamentally paying attention to the students' learning environment, strategies, methods and approaches [5].

\section{B. Build Open Tourism Teaching Environment; Stimulate Students' Interest in Learning in Tourism}

The construction of the teaching environment construction is an important part of the teaching mode, professional tourism management not only require students to master in management, economics, marketing and other basic knowledge, but also be familiar with hotel, travel agencies, tourist scenic spot, exhibition center and other related tourism enterprise management of the basic principle. Construction of the open tourism teaching environment and implementation is the "simulation sand table "teaching. At the same time, the teaching environment construction should be strengthened to society and the relevant enterprises and institutions to contact and cooperation, practical training base construction.

\section{Elaborate Design Experiential Teaching Process, Innovation Tourism Teaching Methods}

Experience type teaching mode in the teaching process for elaborate conception and design, so in the design must take students "learning" in the first position, it's not experience type teaching requirements, but also the needs of The Times. According to the experience type teaching mode process and combined with the characteristics of tourism management major, we can design the experience type teaching process as shown in figure 1 .

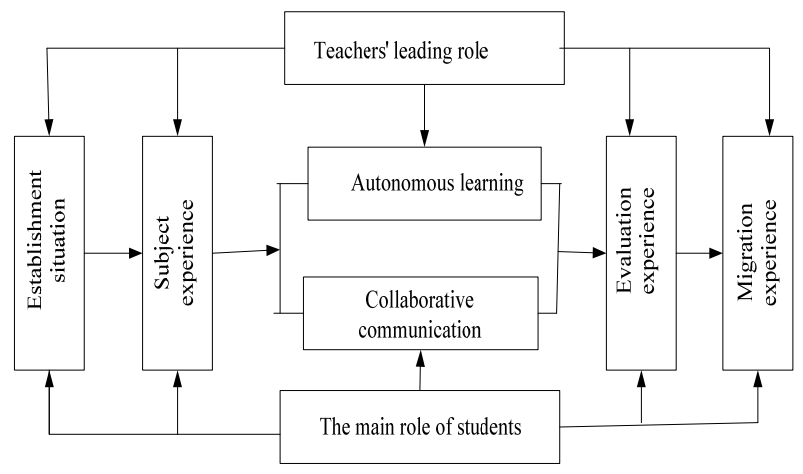

Figure 1. Tourism management professional experience type teaching process

\section{IMPLEMENTATION WAY OF TOURISM MANAGEMENT Professional EXPERIENCE TyPe TEACHING Mode}

\section{A. The Multivariate and Interactive Experience Teaching in Class Teaching}

1) Theme Teaching Experience.The so-called theme experience teaching, which is around a teaching content, combined with teaching material and reference the related concept, principle, data, materials and so on comprehensive arrangement, Combined with the actual situation of tourism industry, with special subject lecture form show students of a teaching method..

2) Case Type Teaching Experience.Case type experience teaching in the students master the basic knowledge and analysis technique foundation, on the teacher's careful planning and guidance, according to the teaching aims and teaching content requirements, using typical events, typical students into specific event site specific analysis, Through the student independent thinking or collective collaboration, to further improve the identification, analysis and solve a specific problem of ability, and cultivate the correct management idea, work style, communication skills and teamwork spirit in the teaching mode. The characteristic of this kind of means is the theory knowledge into the typical case, so that the students can combine practical problems to study, understand the theoretical knowledge [6].

3) Scene Analog Experience Teaching. The so-called situation analogous experience teaching, is to follow the principle of the reflection theory, and make full use of the image to create vivid specific teaching situation, through the role playing, stimulate students' learning mood, potential wisdom, So as to guide students to whole understand and use , promote the students' knowledge, character, ability of harmonious development.

\section{B. Organize rich and Colorful Tourist Extracurricular Experience}

1) Project Type Experience Teaching. For a long time, the institutions of higher learning classroom basic is adhering to the high school "cramming" teaching method, students' lack of learning initiative and self-consciousness, One of the important problem is the lack of guidance and appropriate subject. tourism management Professional many specialized courses can use increase their design, through the social project research, guide the students to study, cultivate the ability to solve problems.

2) Social Investigation and Visit.Social survey and visit experience is the student contact the society and know the outside world an important way, it helps to enhance students to social life accumulation, and access to social corresponding material culture and spiritual culture, system culture, is the student understanding, experience, feeling of social learning activities, It makes students' social experience, 
life accumulation and cultural accumulation gradually deep, the students' learning and growth has an important role.

3) Professional Skill Activities. Tourism management professional practice very strong, often requires the student to have the strong practical ability. Therefore, we need to give students actively create opportunities, let the students contact and exercise their practical ability. Schools should actively contact tourism enterprises can professional skills of observation,, use of various social resources, all kinds of audio-visual material for students to create complex teaching activities experience.

\section{SUMMARY}

Experience type teaching mode of the value not only put forward a kind of teaching mode, more important is to provide a help to students' subjective development idea, really reflect the quality education values. Experience type teaching guide students from passive to active, from dependence to independence, finally achieve promote the subjectivity full and free development of purpose. It not only stimulate the students' thinking, encourage students to participate in, so that every student in the classroom, become a real class master, make the class filled with the vitality of life, more to improve the effectiveness of classroom teaching.

\section{REFERENCES}

[1] S.F. Hu, T.Tao, "Experience type teaching mode trial ,"Education explores. 2003, (11): pp.49-51

[2] Y.T.Yu, Q.L.Chen etc, “Experience teaching theory research,”journal of contemporary education BBS. 2006 (4): pp.60 -61.

[3] C.X.Dong, G.Y.Wang, "Tourism education teaching model ,"Economist. 2004, (2): pp.139-141.

[4] J.P.Li, "experience type teaching method in management teaching application ,"Heilongjiang education. 2006, (10): pp.59 - 60

[5] Y.F. Pan, "Tourism Management Teaching Mode Innovation. ,"Zhejiang Shuren University Journal. 2006, ( 2) : pp.55 59

[6] X.X.Xie, J.Wu, "Theory experience thinking in the application of tourism management teaching,"Journal of tourism education supplement. 2006 (S): pp.111-113. 